\title{
Editorial Foreword 73.1 (February 2014)
}

\section{Our Cover}

Our cover image is a figure from Eiko Maruko Siniawer's article on the affective meaning of wastefulness in Japan. The illustrations are from a children's book by Akiyama Hiroko, who, in a three-volume series, compared people's approaches to conservation and wastefulness in Edo and contemporary Tokyo. ${ }^{1}$ In this figure, the two children featured in the book go back in time. As Siniawer points out in her article, "On one page, the two children were on the dirty streets of Tokyo pointing out the garbage in the river, the discarded cigarette butts on the sidewalks, the usable goods that had been thrown out as trash, and the household garbage deposited curbside that had been strewn about by scavenging crows. On the next page, the pair found themselves in Edo, where the sister exclaimed, 'There are so many people in Edo, but the streets are clean!'”

\section{REFLECTIONS}

This issue opens with a poignant pair of brief essays: "Partition: 'The Pulsing Heart that Grieved," by religious studies scholar GERALD James LARSON, who is one of the Journal's two associate editors for South Asia, and "Idols in the Archive" by historian Manan Ahmed Asif. Together, these commentaries comprise the second in our ongoing series "Reflections," which we inaugurated last year with historian Paul A. Cohen's elegant assessment of journalist Peter Hessler's unusually influential trilogy of books on China. Here, again, we showcase writing that combines scholarly concerns with an effort to engage readers in ways, including highly personal modes of expression, not often found in mainstream academic journals. Larson's contribution, on the religious shock waves triggered by the mid-century creation of India and Pakistan as independent states, while a thoughtful essay in its own right, also serves a special purpose. This is to provide a context to help readers in fields other than South Asian studies appreciate the stakes of the deeply personal and erudite remarks by Asif that follow and the images that accompany those remarks.

Each contribution to the "Reflections" series will, we hope, provide some element of surprise to the reader. In the essay that inaugurated the feature, that sense of the unexpected came in part from the fact that a senior scholar, known in part for a major survey of American academic writing on China, was focusing on books by someone outside of the academy, and began his ruminations by describing a visit to a bookstore. In the case of

\footnotetext{
${ }^{1}$ Akiyama Hiroko, Gomi o herasu chie [Advice for reducing garbage], vol. 1 of Edo no kurashi kara manabu "mottainai" ["Mottainai" learned from Edo living] (Tokyo: Chōbunsha, 2009), 4-5.
} 
Asif's "Idols in the Archive," it comes in part from the mixture of memoir and visual materials offered to readers and the way they are woven together. It also comes, though, from the tone and timbre of the author's writing, which Larson aptly dubs "poetic" and which includes lines such as these that open its second paragraph: "Body was the first archive I learned to read. I used to gaze at my grandmother's hands in wonder, knowing that each crease and crevice had a specific memory, a song, and maybe a story about Kashmir."

\section{Research Articles}

Usually, readers will note a clear shift in style when moving to the main section of the Journal from the "front of the book" shorter pieces—works that fit into the "Asia Beyond the Headlines," "Trends," or "Reflections" genres_but this issue is an exception. Why? Because the first standard research article of this issue of the Journal is anthropologist Erik Muegglen’s “Corpse, Stone, Door, Text." It is much longer than "Idols in the Archive" and draws on fieldwork and textual analysis rather than memory, yet it, too, as its very title suggests, is written in a manner unusually attuned, at least for scholarly writing, to such qualities as cadence. Those familiar with previous work that Mueggler has done, for this publication and others, have come to expect prose that is not far removed from poetry, and this is true again in his discussion here of the way that burial stones in a part of Southwest China heavily populated by "Tibeto-Burman-speaking peoples," such as the Yi, "became replacements for corpses, doors to the underworld, narratives of lives, and textual diagrams of kinship relations."

Following Mueggler’s essay is Justin M. JaCOBs’s “Nationalist China’s ‘Great Game’: Leveraging Foreign Explorers in Xinjiang, 1927-1935," which moves us from the southwestern to the northwestern borderlands of today's PRC. In disciplinary terms, meanwhile, it takes us from those of ethnography to those of the new international history, attentive both to conventional diplomatic issues and cultural issues, in this case those of archaeological digs. Making the most of newly available documents and focusing on the famous, as well as controversial, "expeditions of Aurel Stein and Sven Hedin," Jacobs "demonstrates how the discourse of cultural sovereignty . . became the handmaiden of domestic geopolitical competitors who attempted to turn" the Western explorers who led the digs "into exploitable resources for their own agendas."

Next comes Projit Bihari Mukharjı's "Vishalyakarani as Eupatorium ayapana: Retro-botanizing, Embedded Traditions, and Multiple Historicities of Plants in Colonial Bengal, 1890-1940," a contribution to history and science studies. At one level, it is a case study that traces various efforts made to "identify a medicinal herb" and figure out what it should be called, but at another, it is a bold foray into an ongoing debate, involving scholars in many fields, over the relationship between "historical and mythic pasts." This is because the plant in question has sometimes been associated with one that is "mentioned in some versions of the Ramayana," a highly significant South Asian text. Mukharji sees the complex tales of arguments over its nomenclature as illustrating that the "allegedly watertight distinction" between myth and history is, in fact, anything but.

Following this, we move to Southeast Asia for the first time in this issue with Francis R. Bradley's look at connections between this region and the Middle East. 
In "Islamic Reform, the Family, and Knowledge Networks Linking Mecca to Southeast Asia in the Nineteenth Century," Bradley makes use of a very unusual collection of texts: “over 1,300 previously unanalyzed Malay Islamic manuscripts." Through close analysis of these materials, the historian unravels and helps us understand the construction, workings, and shifts over time of "transoceanic knowledge networks" that tied together people living geographically far from one another, yet linked together via shared religious traditions, rituals, and ideas about the family.

Next up is Nayoung Aimee Kwon's "Conflicting Nostalgia: Performing The Tale of Ch'unhyang (春香傳) in the Japanese Empire,” which explores the reception, especially in Korea and Japan, of a bilingual author's dramatization of a Korean folktale. In this foray into literary and cultural analysis, Kwon examines a "forgotten moment of colonial 'collaboration' between Korea and Japan when the two countries' literary histories converged in a widely publicized performance across the empire." The author sees the play, which meant very different things to different audiences, as having a much more complex significance than the "embodiment of harmonious imperial assimilation" that it was "touted at the time" to be. Indeed, it can be read as showcasing "anxieties" that ran through the relations between colonizers and colonized and have continued to influence interactions across national divides in postcolonial times.

Completing the main section of the Journal are two very different research articles that share a common focus on developments that followed Japan's brief imperial period. The first of the two postwar Japan research articles - each of which deals in part or in full with what is sometimes in fact called Japan’s "post-post-war” era-is KumiKo SaITo’s "Magic, Shōjo, and Metamorphosis: Magical Girl Anime and the Challenges of Changing Gender Identities in Japanese Society." It is a wide-ranging look at a popular and evolving genre that features a distinctive type of female hero figure, and has much to offer readers who enjoyed Christine Yano's "Asia Beyond the Headlines" essay on the global reach of Japanese popular culture that appeared in an earlier issue of this journal. ${ }^{2}$ Saito brings in, among other intriguing topics, the way "recent tendencies for gender bending and genre crossing" in this kind of anime "raise critical questions about the spread of the magical girl trope as cute power."

Closing out the main section of the Journal is “'Affluence of the Heart': Wastefulness and the Search for Meaning in Millennial Japan” by historian Eiko Maruko Siniawer, the piece from which our cover image is drawn. The author, focusing on the first decade of this century, examines "how discourses" of that time that "were ostensibly about wastefulness constituted an articulation of values" that was linked to "a certain conception of affluence." Debates over what exactly should be seen as "wasteful," according to this, were part of a process of coming to an "uneasy acceptance of economic stagnation" and expressed a "desire to find meaning in an economically anemic, yet still affluent, Japan."

In another segue between parts of the issue, such as the one between Asif and Mueggler's contributions noted above, this pair of research articles is followed, at the start of the "back of the book" review section, by Franziska Seraphim's "A New Social

${ }^{2}$ Christine R. Yano, "Wink on Pink: Interpreting Japanese Cute as It Grabs the Global Headlines," Journal of Asian Studies 68, no. 3 (August 2009): 681-88. 


\section{Editorial Foreword}

History of Occupied Japan"- a review essay that looks at a trio of recent publications that take up, in various ways, John Dower's call for new work on an "intense, unpredictable, ambiguous, confusing, and electric" period of the Japanese past.

\section{Forthcoming Articles in JAS 73.2 (May 2014)}

\section{Asia Beyond the Headlines}

Playing by Unfair Rules? Asia’s Positioning within Global Sports Production Networks Wolfram Manzenreiter

\section{Research Articles}

Let's Go to the Moon: Science Fiction in the North Korean Children's Magazine Adong Munhak, 1956-1965

DAFNA ZUR

Comment on Zur

Nico Volland

From "Nourish the People" to "Sacrifice for the Nation": Changing Responses to Disaster in Late Imperial and Modern China

Kathryn Jean Edgerton-Tarpley

Comment on Edgerton-Tarpley

Paul Greenlough

Murder! in Thailand's Vernacular Press

SAMSON W. LIM

From Praśasti to Political Culture: The Nadia Raj and Malla Dynasty in SeventeenthCentury Bengal

SAmuel Wright

Picturing Pure Lands: Pilgrimage and Cosmography in the Court of the Thirteenth Dalai Lama (1876-1933)

Wen-Shing Chou

Storming the Citadels of Poverty: Family Planning under the Emergency in India, 1975-1977

Rebecca Jane Williams

Existentialism and Intellectual Culture in South Vietnam WyNN WiLCOX

The 1903 Human Pavilion: Colonial Realities and Subaltern Subjectivities in 20th Century Japan

Kirsten Ziomek 